A RESPONSABILIDADE CIVIL EXTRACONTRATUALDO ESTADO POR ATO ADMINISTRATIVO NO ORDENAMENTO JURÍDICO PORTUGUÊS: UMA TRIPLA PERSPECTIVA DO REGIME DA RESPONSABILIDADE: DELITUAL, PELORISCOEPORFATOLÍCITOI THENON-CONTRACTUAL CIVIL LIABILITY OF THE STATE IN ADMINISTRATIVE ACTS FOR THE PORTUGUESE LEGAL SYSTEM: TORTIOUS LIABILITY, RISK LIABILITY AND LEGAL LIABILITY

\title{
PATRÍCIA PINTO ALVES
}

RESUMO | Neste trabalho abordarse-á a temática da responsabilidade civil extracontratual do Estado e demais Entidades Públicas pelo exercício da função administrativa no ordenamento jurídico português. Serão tecidas considerações acerca das variadas modalidades de tal responsabilidade: delitual (por fatos ilícitos), pelo risco e por fatos lícitos - na medida em que pode haver responsabilidade da Administração Pública (AP), em certas situações em que a sua conduta seja efetuada de forma lícita. Será enaltecida a relevância da Lei n. ${ }^{\circ}$ 67/2007, de 31 de dezembro, em articulação definida com a Constituição da República Portuguesa, com o Código Civil, e com o Código das Expropriações Português.

PALAVRAS-CHAVE | Responsabilidade. Estado. Ilicitude. Licitude. Indenização pelo sacrifício.
ABSTRACT | This paper addresses the non-contractual civil liability of the State and Public Entities for the administrative functions of the Portuguese legal order. This paper discusses considerations about the varied types of liability: tortious (which comprehends illicit facts), risk liability, and liability for licit facts [because it could acknowledge Public Administration liability in situations where its practice is conducted on a licit way]. Finally, this article also mentions the relevance of Portuguese Law No. 67/December 31, 2007, together with the Constitution of the Portuguese Republic, with the Civil Code, and with the Portuguese Expropriation Code.

KEYWORDS I Liability. State. Unlawfulness. Lawfulness. Compensation for sacrifice. 


\section{NOTA PRÉVIA}

Whe king can do no wrong: pois, não mais. O regime de responsabilização surge como uma conquista do Século $X X$ e do Estado Social de Direito. A Constituição da República Portuguesa de 1976 (CRP) consagrou o princípio da responsabilidade solidária dos Poderes Públicos e dos que agem em seu nome no respectivo exercício de funções, dele decorrendo o direito fundamental dos particulares à reparação de danos (direito de natureza análoga a direitos, liberdades e garantias, art. $22 .^{\circ}$ da CRP ${ }^{1}$ ). E, entre nós, para lhe dar concretização existe a recente Lei n. ${ }^{\circ}$ 67/2007, de 31 de dezembro (RRcivilEEE).

Não obstante parecer ser tão inovadora (sobretudo no confronto com o regime anterior, é certo), a verdade, porém, é que a nova disciplina da responsabilidade civil extracontratual do Estado e Demais Entidades Públicas (Lei n. ${ }^{\circ}$ 67/2007, de 31 de dezembro, RRcivilEEE) não é, afinal, assim tão surpreendente e inovadora quanto seria desejável. E assim é, porque, por um lado, o legislador só veio a nela acolher as soluções ditadas pela jurisprudência administrativa até 2007 e porque padece de muitas insuficiências, mormente no que respeita a responsabilidade do Estado por danos decorrentes do incumprimento do Direito da União Europeia, por exemplo.

1 Parafraseando Fernando Alves Correia, «(...) é no artigo 22. ${ }^{\circ}$ da Constituição que, devido à sua formulação ampla, se encontra o fundamento constitucional da responsabilidade civil extracontratual por fatos ilícitos e culposos praticados no exercício da função administrativa, da função legislativa e da função jurisdicional, norma essa que deve ser interpretada em conjugação com outros preceitos constitucionais atinentes à responsabilidade civil dos titulares dos órgãos, funcionários e agentes, como o artigo 271 (responsabilidade civil dos funcionários e agentes do Estado e das demais entidades públicas), o artigo $117, n .{ }^{\circ} 1$ (responsabilidade civil dos titulares de cargos políticos pelas ações ou omissões que pratiquem no exercício das suas funções), e o artigo $216, n .{ }^{\circ} 2$ (responsabilidade civil dos juízes)». Cfr. Fernando Alves Correia (2012, p. 213). 
Em abono da verdade, o RRcivilEEE não levou em conta (ou levou pouco em conta) o problema da responsabilidade do Estado por danos decorrentes do incumprimento do Direito da União Europeia, ignorando-o (quase) na totalidade. De fato, deveria ter sido levado em conta o artigo $9^{\circ}, \mathrm{n} .^{\circ} 2$, a propósito da responsabilidade pelo exercício da função administrativa; no artigo $13^{\circ}$, no quadro do regime da responsabilidade por fato imputável ao Estado-juiz, devendo mencionar o erro judiciário por erro na interpretação ou aplicação do Direito da União europeia, sendo certo que, ao estabelecer o pressuposto da prévia revogação da decisão danosa pela jurisdição competente, o regime da Responsabilidade do Estado-juiz por erro na interpretação e aplicação do Direito da União Europeia não vai ao encontro da jurisprudência do Tribunal de Justiça (doravante $T J$ ), devendo afastar-se ${ }^{2}$. Levou-se em conta apenas a disciplina da responsabilidade por fato imputável ao Estado-legislador, nos termos do artigo 15. E levou em consideração no domínio da responsabilidade pelo exercício da função administrativa por atos ilegais praticados pelas entidades adjudicantes no domínio de quatro contratos públicos (nos termos do artigo $7^{\circ}$, n. ${ }^{\circ} 2$, em resultado da primeira alteração ao RRcivilEEE).

É um fato que deste novo regime há um traço que se deve de imediato louvar e por força do qual é possível responsabilizar o Estado-Administração, o Estado-Juiz e o Estado-Legislador, sendo certo que esta disciplina prevê um regime distinto para apurar o dever de reparar os danos decorrentes do exercício da função administrativa (especialmente nos termos dos artigos $7^{\circ}$ e seguintes), a função jurisdicional (nos termos dos artigos 12 , 13 e 14) e a função Político-legislativa (nos termos do artigo 15).

Em face das fragilidades, há que convocar uma metodologia 2 Sobre a temática, e para consulta do acervo bibliográfico lá indicado, $v d$. Isabel Fonseca (2008), e Isabel Fonseca (2011, pp. 189 e ss). Em especial, $v d$, Maria José Rangel de Mesquita (2010, pp. 29 e ss); Carla Amado Gomes (2010, pp. 261 e ss.). 
de superação: o juiz nacional, enquanto juiz comum do Direito da União Europeia, deve seguir a jurisprudência do TJ em moldes idênticos nas situações de incumprimento do direito da União Europeia imputável ao Estado-Administração, ao Estado-legislador e ao Estado-juiz, não variando, portanto, os pressupostos da responsabilidade de raiz comunitária ${ }^{3}$.

\section{RESPONSABILIDADE CIVIL EXTRACONTRATUAL PELO EXERCÍCIO DAFUNÇÃO ADMINISTRATIVA: ASPECTOS MAIS TRANSPARENTES}

É precisamente com este propósito que surge a expressão responsabilidade civil, tendo em vista a reparação do dano. Em relação ao regime de responsabilização civil relativo a danos 3 No que diz respeito à responsabilidade do Estado-juiz e à metodologia de proteção do direito à emissão de sentença em prazo razoável, importa perceber que esta assenta num apertado diálogo entre a jurisdição nacional e a de Estrasburgo, sobretudo traduzido numa lógica de levar em conta o precedente europeu, sendo incontestável também que o juiz europeu vai fixando novos graus de exigência, que os juízes nacionais têm que levar em conta, em cada momento, mesmo quando pensam que os passos já dados pelo legislador são suficientes. A consideração do Direito Europeu reforça a natureza objetiva (com função meramente reparadora) da responsabilidade do Estado. E assim é porque, no quadro da União Europeia, a culpa deve presumir-se a partir da ilicitude inerente à "violação suficientemente caraterizada", não devendo constituir um requisito autônomo ou complementar concebido em termos tais que dificulte ou impeça a efetivação do direito à indenização para além daquilo que o direito comunitário dispõe. No quadro do Direito emergente do Conselho da Europa, não havendo lugar a apurar da culpa, importa aferir da ilicitude, do dano e do nexo de causalidade entre fato ilícito e dano, sendo certo que se impõe acolher a orientação do Tribunal Europeu dos Direitos do Homem (TEDH) no que diz respeito à consideração do dano não patrimonial, sendo este dano ínsito ao dano indenizável, devendo presumir-se a sua existência nos termos do id quod plerumque accidit, sendo certo que, quanto ao quantum debeatur, de acordo com o TEDH, por cada ano de atraso, o lesado deve obter uma indenização suficiente que deve ser calculada de acordo com o critério dos casos semelhantes ou da mesma espécie, segundo o modelo europeu. 
decorrentes do exercício da função administrativa, impõe-se registrar duas ou três novidades introduzidas há pouco no panorama legislativo português, sendo certo que ao exercício da função administrativa correspondem às ações ou omissões adotadas no exercício de prerrogativas de poder público ou reguladas por disposições ou princípios de Direito Administrativo, incluindo a atividade desenvolvida por Entidades Públicas, titulares dos respectivos órgãos e funcionários e agentes públicos (e trabalhadores a serviço dessas entidades públicas abrangidas) e pessoas coletivas de direito privado (e seus agentes) por ações ou omissões que adotem no exercício de prerrogativas de poder público ou que sejam reguladas pelo Direito Administrativo.

Neste regime impõe-se distinguir a responsabilidade delitual (assente na ilicitude e culpa, nos termos dos artigos $7^{\circ}$ a $9^{\circ}$ do RRcivilEEE) da que existe sem que a culpa do agente se deva considerar para que haja obrigação de reparação do dano (o que, sendo objetiva, abrange, nos termos dos artigos a responsabilidade pelo risco, nos termos do artigo 11, pressupondo a produção de danos decorrentes de atividades, coisas ou serviços administrativos especialmente perigosos, e a responsabilidade por imposição de sacrifício, nos termos do artigo 16 , correspondendo o dever de indenizar os particulares a quem imponham encargos ou causem danos especiais e anormais, por razões de interesse público - sendo certo que serão especiais os danos ou os encargos que incidam sobre uma pessoa ou um grupo, sem afetarem a generalidade das pessoas e, sendo certo ainda que serão anormais os que, ultrapassando os custos próprios da vida em sociedade, mereçam pela sua gravidade a tutela do direito).

De um modo ou de outro, o instituto da responsabilidade civil administrativa é o conjunto de circunstâncias da qual emerge, para a Administração Pública e para os seus titulares de órgãos, funcionários ou agentes, o dever de indenização 
dos prejuízos causados a outrem no exercício da atividade administrativa. Portanto, o qualificativo civil da responsabilidade não remete para o direito privado, tratando-se tão somente de esclarecer que a responsabilidade em causa não é política, criminal, contraordenacional ou disciplinar, sendo certo que se diz responsabilidade extracontratual por pressupor afetação de direitos subjetivos ou interesses legalmente protegidos ${ }^{4}$, sendo administrativa por relevar a imputação funcional, sendo certo que o fato voluntário tem de ser imputado a um titular de órgão ou agente (ou ainda trabalhador) de uma pessoa coletiva administrativa (pressupondo a investidura de uma pessoa física em tal estatuto, ainda que se possam suscitar alguns problemas quando tal investidura resulte de atos jurídicos nulos ou inexistentes); pressupondo também que seja praticado no exercício das funções do titular de órgão e por causa dessas funções.

\section{A RESPONSABILIDADE CIVIL EXTRACONTRATUAL POR ATO ADMINISTRATIVO: ASPECTOS MAIS DIFÍCEIS}

Tratando-se de atos funcionais, o dever de indenizar ${ }^{5}$ que emerge da responsabilidade civil delitual pode impender, quer $4 \quad$ Por todos, $v d$, Marcelo Rebelo de Sousa/André Salgado de Matos (2008, pp. 16-17).

$5 \quad \mathrm{O}$ artigo $3^{\circ}$ do RRcivilEEE tem por epígrafe "Obrigação de indenizar". Assim, dispõe no seu n. 1 que: "Quem esteja obrigado a reparar um dano, segundo o disposto na presente na lei, deve reconstituir a situação que existiria se não se tivesse verificado o evento que obriga à reparação". No seu n. 2 consagra que: "A indenização é fixada em dinheiro quando a reconstituição natural não seja possível, não repare integralmente os danos ou seja excessivamente onerosa". Daqui retira-se a regra da reconstituição in natura. Explana, por sua vez, $\mathrm{o} n{ }^{\circ} 3$ deste preceito legal que: "A responsabilidade prevista na presente lei compreende os danos patrimoniais e não patrimoniais, bem como os danos já produzidos e os danos futuros, nos termos gerais de direito". Isto sucede, no entanto, no ordenamento jurídico português. Mas, esta forma de indenização já assim não é na França 
exclusivamente sobre a pessoa coletiva a que é imputado o fato que gera o prejuízo (artigo $7 .^{\circ}$ do RRcivilEEE), quer também sobre o titular de órgão ou agente que o praticou (artigo $8 .^{\circ}$ do RRcivilEEE).

Haverá responsabilidade civil da pessoa coletiva pública e dever de indenizar, assim que se verifiquem preenchidos de forma cumulativa cinco pressupostos, expressa ou implicitamente resultantes dos artigos $7^{\circ}$, n. $^{\circ} 1$ e $8^{\circ}$, n. $^{\circ} 1$ e 2 do RRcivilEEE: o fato voluntário, a ilicitude, a culpa, o dano e o nexo de causalidade, bastando a não verificação do preenchimento de um destes pressupostos para acarretar de forma automática a inexistência de responsabilidade delitual, embora possa ainda haver lugar a outro tipo de responsabilidade civil ou mesmo a outra pretensão reintegratória (assim, se faltar o pressuposto da ilicitude, pode haver lugar a responsabilidade por fato lícito ou pelo risco ou a uma pretensão indenizatória pelo sacrifício de direitos patrimoniais privados; se faltar o pressuposto da culpa pode ter lugar a pretensão à reconstituição da situação atual hipotética ou o enriquecimento sem causa).

Quanto ao fato voluntário, só há responsabilidade civil delitual por danos resultantes de fatos humanos, domináveis pela vontade - isto é, de atos em sentido próprio, que podem consistir,

\footnotetext{
e na Espanha, na medida em que a regra em tais ordenamentos jurídicos é a da indenização em dinheiro, podendo, todavia, o lesado (assim querendo), optar pela reparação em espécie, verificados determinados requisitos. Cfr. Jean-Bernard Auby/ Moreau (2010, Fasc. 81, anotation n. ${ }^{\circ} 66$ ). Para o ordenamento jurídico espanhol, $v d$, entre outros, a respeito, Jesús González Péres (2009, pp. 348-352). Uma última ressalva a ser feita neste âmbito indenizatório é ainda relativamente ao caso Alemão. Na Alemanha apenas é admissível a reparação dos danos ilegalmente provocados por ato jurídico público (de autoridade) recorrendo-se, para os devidos efeitos, à atribuição de indenização de cariz monetário. Neste sentido último, vd, Detterbeck/ Windthorst/Sproll (2000, pp. 204-205, § 11, anotação 10). Como é aceitável, apesar de todos estes países mencionados integrarem a União Europeia, cada um rege-se por legislações autônomas.
} 
quer em ações, quer em omissões (artigos $7^{\circ}, \mathrm{n}^{\circ} 1 \mathrm{e} 8^{\circ}, \mathrm{n} .^{\circ \mathrm{s}} 1 \mathrm{e}$ 2 do RRcivilEEE), constituindo ações os regulamentos e os atos administrativos, assim como as simples atuações administrativas e os atos reais, incluindo todas as omissões juridicamente importantes. Apesar desta exigência, a relevância das omissões é maior na responsabilidade administrativa ${ }^{6}$.

Quanto à ilicitude do fato voluntário (artigos $7^{\circ}, \mathrm{n} . .^{\circ} 1$ e $8^{\circ}, \mathrm{n} .{ }^{\mathrm{os}}$ 1 e 2 do RRcivilEEE), esta é sinônimo de antijuridicidade, que se expressa num juízo negativo (ou desvalor) formulado pela ordem jurídica (predominantemente incidente sobre o fato ou sobre o seu resultado, consoante os casos). llícita é qualquer conduta que viole o bloco de legalidade (que seja ilegal): assim, são ilícitos os atos que violem princípios ou regras constitucionais, legais ou regulamentares (ou ainda internacionais ou comunitários) ou infrinjam regras técnicas ou deveres objetivos de cuidado (artigo $9^{\circ}$, n. $^{\circ} 1$ do RRcivilEEE), assim como aqueles que violem os parâmetros pelos quais deve reger-se o funcionamento normal dos serviços (artigo $9^{\circ}, \mathrm{n} .^{\circ} 2$ do RRcivilEEE).

Para haver responsabilidade civil delitual, a ilegalidade deve consistir na violação da norma que tutela a posição jurídica subjetiva cuja lesão se pretende ver reparada (Ac. do STA de 31/5/2005, Proc. n. ${ }^{\circ}$ 0127/03; o mesmo decorre implicitamente da última parte do artigo $9^{\circ}$, n. $^{\circ} 1$ do RRcivilEEE). Há duas modalidades básicas de ilicitude: a ilicitude por violação de direitos subjetivos e a ilicitude por violação de normas destinadas a proteger interesses (normas de proteção). No primeiro caso, incluem-se quaisquer direitos subjetivos (direitos fundamentais, de personalidade, reais, familiares, de propriedade intelectual ou industrial), salvo quando se trate da ofensa de direitos de crédito emergentes de contratos, perpetrada pelo devedor, que gera responsabilidade contratual; no segundo, incluemse os interesses legalmente protegidos. Há ainda previsões 6 Marcelo Rebelo de Sousa/André Salgado de Matos (2008, p. 20). 
específicas de ilicitude para efeitos de responsabilidade civil administrativa, designadamente a decorrente da prestação de informações ${ }^{7}$.

A culpa como pressuposto da responsabilidade civil delitual (artigos $7^{\circ}, \mathrm{n} .{ }^{\circ} 1$ e $8^{\circ}$, n. $^{\circ} \mathrm{s} 1$ e 2 do RRcivilEEE) consiste na preterição da diligência pela qual a lei exigia que o autor do fato voluntário e ilícito tivesse pautado a sua conduta ou o seu comportamento. Assim, quando falamos em culpabilidade, falamos do juízo formulado pela ordem jurídica sobre quem age com culpa. A palavra "culpa" é, por vezes, utilizada restritamente para designar a negligência (por exemplo, artigos $7^{\circ}, n .{ }^{\circ} 1$ e $8^{\circ}$, n. ${ }^{0} 1$ do RRcivilEEE).

São modalidades de culpa o dolo e a negligência. O dolo pressupõe a intenção de provocar um determinado resultado danoso [dolo direto, se o autor do fato voluntário pretender primariamente a produção desse resultado; dolo necessário, se o autor do fato voluntário pretender primariamente a produção de outro resultado cuja verificação implica necessariamente a produção do resultado danoso ou, pelo menos, a conformação com a produção de tal resultado (dolo eventual)] $]^{8}$. Já a negligência pressupõe a violação, consciente ou inconsciente, de deveres de cuidado. Quando a diligência empregue tenha sido manifestamente inferior àquela a que o titular de órgão ou agente se encontrava obrigado em razão do cargo por si ocupado (artigo $8^{\circ}$, n. ${ }^{\circ} 1$ do RRcivilEEE), estamos perante a negligência dita grave, sendo certo que, podendo estar na fronteira com o dolo eventual, é possível ainda identificar uma forma de negligência grosseira, que não tem relevância normativa autônoma); nas demais situações, diz-se leve (artigo $7^{\circ}, \mathrm{n} .^{\circ} 1$ do RRcivilEEE ). $7 \quad$ Ainda quanto à ilicitude, as causas de justificação da ilicitude são o cumprimento de um dever, o estado de necessidade, o consentimento do lesado e a legítima defesa. Sobre este assunto, por todos, $v d$, Marcelo Rebelo de Sousa/André Salgado de Matos (2008, p. 21).

8 Marcelo Rebelo de Sousa/André Salgado de Matos (2008, pp. 25-26). 
Assim, em suma, é grave ou leve conforme a diligência empregue tenha sido manifestamente inferior (ou não) àquela a que o titular do órgão ou agente se encontrava obrigado em razão do cargo por si ocupado.

A distinção entre a negligência grave e a negligência leve é da maior relevância na responsabilidade administrativa: para a responsabilização das pessoas coletivas administrativas chega qualquer tipo de negligência (artigo $7 .^{\circ}, \mathrm{n} .{ }^{\circ} 1$ do RRcivilEEE), mas a responsabilidade dos titulares de órgãos ou agentes pressupõe pelo menos a negligência grave (artigo $8^{\circ}, \mathrm{n} .^{\circ} 1$ do RRcivilEEE).

A culpa é apreciada à luz da diligência e aptidão que seja razoável exigir, em função das circunstâncias de cada caso, de um titular de órgão ou agente cumpridor e zeloso (artigo 10, n. ${ }^{\circ} 1$ do RRcivilEEE), convocando-se o modelo da diligência e a aptidão de um titular de órgão ou agentes médios. As "circunstâncias de cada caso" não podem deixar de levar em conta os deveres funcionais do concreto titular de órgão ou agente (artigo $8^{\circ}$, n. $^{\circ}$ 1 do RRcivilEEE, parte final), de forma a que seja respeitado o princípio que nos diz que ninguém é obrigado a mais do que aquilo que pode fazer (ultra posse nemo obligatur), mas também de forma a evitar que as condutas de titulares de órgãos ou agentes administrativos de topo sejam avaliadas segundo padrões de diligência benevolentes em razão da relevância das funções que Ihes estão cometidas?.

Há situações em que, apesar de ser objetivamente comprovável que um determinado dano se produziu em virtude da má organização ou do mau funcionamento de um serviço público, não é possível identificar o autor ou os autores dos fatos que lhes deram origem; isto ocorre com mais frequência em situações de omissão. Aplicando estritamente os requisitos da responsabilidade civil, teria que concluir-se não ser possível a sua efetivação prática, na medida em que, desconhecendo-se o autor 
do fato a quem respeitam as circunstâncias subjetivas relevantes, não seria possível formular os juízos de dolo ou negligência dos quais depende o preenchimento do pressuposto da culpa da responsabilidade civil (em alguns casos, nem sequer seria possível identificar uma conduta à qual imputar o fato danoso). Tal solução seria iníqua para o lesado e contrariaria os fundamentos da responsabilidade delitual, motivo pelo qual se admite, neste caso, a responsabilização da pessoa coletiva a que pertença o serviço em causa sem ser preciso proceder ao apuramento da culpa individual (artigo $7^{\circ}$, n. $^{\text {os }} 3$ e 4 do RRcivilEEE), mediante averiguação da diligência diretamente em relação ao serviço público no âmbito do qual se produziu o fato danoso: existirá, assim, "funcionamento anormal do serviço" quando este esteja organizado ou tenha funcionado objetivamente com uma diligência inferior àquela que era normativamente exigida (o artigo $7^{\circ}, \mathrm{n}^{\circ} 4$ do RRcivilEEE é ambíguo quando se refere aos "padrões médios de resultado" e muito restrito, por parecer reduzir-se às omissões, quando se refere a "uma atuação suscetível de evitar os danos produzidos"). A noção de funcionamento anormal do serviço é, pelo menos em parte, um sucedâneo da culpa; sendo por isso que, tradicionalmente, se falava mesmo em culpa do serviço.

Quanto à prova da culpa ${ }^{10}$ e presunções de culpa, a lei não dispõe de forma direta sobre a prova da culpa, devendo, nos termos do artigo $10, n .^{\circ} 2$, considerar-se que sobre a culpa deve incidir uma demonstração, pelo que é ao lesado que cabe o ônus de provar a culpa do autor da lesão. A lei administrativa geral prevê duas presunções legais de culpa leve, que invertem

Para Margarida Cortez: "Um especial juízo de censura poderá ser formulado pelo tribunal nos casos em que a Administração incorre em erro de interpretação de normas de sentido preciso e inequívoco ou quando opta - como por vezes sucede - por contrariar o entendimento pacífico e reiterado dos tribunais sobre uma dada questão jurídica". Cfr. Margarida Cortez (2000, pp. 104-105). 
o ônus da prova, quanto à prática de atos jurídicos ilícitos e em caso de violação de deveres de vigilância (respectivamente artigo 10, n. ${ }^{\circ}$ s 2 e 3 do RRcivilEEE) ${ }^{11}$.

O dano pode ser definido como a diminuição ou extinção de uma vantagem que é objeto de tutela jurídica. É um pressuposto da responsabilidade civil administrativa (artigos $7^{\circ}, \mathrm{n} .{ }^{\circ} 1,8^{\circ}$, n. ${ }^{\circ} 1$ do RRcivilEEE) que decorre da própria função do instituto da responsabilidade civil em geral. A noção de dano para

11 Na falta de presunções de culpa administrativa e na inexistência de normas que determinem a aplicação à administração de presunções de culpa estabelecidas na lei civil, estas têm que considerar-se inaplicáveis à responsabilidade administrativa, em virtude da natureza do direito administrativo como direito comum da função administrativa. $\mathrm{O}$ artigo $10, \mathrm{n}$. $^{\circ}$ 3 do RRcivilEEE contém um elemento perturbador desta conclusão, ao referir que a presunção de culpa leve em caso de violação de deveres de vigilância decorre da "aplicação dos princípios gerais da responsabilidade civil". O sentido desta norma parece não ser o de importar para a responsabilidade civil administrativa todas as presunções de culpa do direito civil, quer porque em tal caso não faria sentido a própria existência do artigo, quer porque o modelo de presunção da culpa leve do RRcivilEEE, sobreponível às situações de responsabilização exclusiva das pessoas coletivas públicas, não parece compatível com o sistema civil de presunções integrais de culpa. A falta de presunções legais de culpa não afasta as chamadas presunções judiciais de culpa, resultantes da experiência do julgador, quanto a condutas ostensivamente ilegais da administração. Em sentido oposto, a jurisprudência administrativa tem-se orientado ultimamente no sentido da aplicação à administração das presunções de culpa estabelecidas na lei civil, mas é de enaltecer que a questão não é pacífica. No sentido da aplicação das presunções de culpa do CC, entre outros, o Ac., do STA de 16/05/2006, Proc. $n .^{\circ} 0121 / 06$.

No que respeita às causas de exclusão da culpa, também um juízo de culpa formulado prima facie pode ser afastado em circunstâncias particulares, acarretando a exclusão da responsabilidade delitual. O RRcivilEEE (também denominado por alguns por RRCEE) não regula em geral tal matéria, resultando, porém, o seu regime da CRP, dos princípios gerais em matéria de responsabilidade civil e penal e dos princípios fundamentais da atividade administrativa. As causas de exclusão da culpa relevantes em matéria de responsabilidade administrativa delitual são o erro desculpável e o estado de necessidade desculpante. 
estes efeitos abrange situações de danos emergentes e lucros cessantes; danos presentes e danos futuros e danos patrimoniais e danos morais, sendo os danos emergentes aqueles que correspondem à privação de vantagens que já existiam na esfera jurídica do lesado à altura da lesão e os lucros cessantes aqueles que correspondem à privação de vantagens que iriam formarse na esfera jurídica do lesado se não tivesse ocorrido a lesão (artigo 564, n. $^{0} 1$ do CC) ${ }^{12}$. De um modo ou de outro, impõe-se evidenciar a solução acolhida no artigo $3^{\circ}$, n. ${ }^{\circ} 1$ do RRcivilEEE, que considera que existe um dever de reconstituir a situação que existiria se não se tivesse verificado o evento, sendo certo

12 Quanto aos danos presentes e danos futuros (art. $3^{\circ}$, n. $^{\circ} 3$ do RRcivilEEE), sendo danos presentes aqueles que já ocorreram no momento da fixação da indenização; e danos futuros aqueles que ainda não ocorreram no momento da fixação da indenização (art. 564, n. ${ }^{\circ} 2$ do CC). Quanto aos danos patrimoniais e danos morais (art. $3^{\circ}, n^{\circ} 3$ do RRcivilEEE; também art. 85, n. ${ }^{\circ} 6$ do Estatuto Disciplinar dos Funcionários e Agentes da Administração Pública (vulgo EDFAAP), os danos são patrimoniais quando suscetíveis de avaliação pecuniária e, dizem-se morais (art. $3^{\circ}, n .^{\circ} 3$ do RRcivilEEE) quando insuscetíveis de tal avaliação pecuniária. Tal artigo remete à matéria para os "termos gerais de direito", pelo que parece dever aplicar-se o art. 496, n. ${ }^{\circ} 1$ do $C C$, que restringe a indenizabilidade dos danos morais aos casos que, pela sua gravidade, mereçam a tutela do direito; isto pouco acrescenta ao critério de delimitação dos danos ressarcíveis, acabando a decisão sobre a ressarcibilidade ou não dos danos por ser relegada para uma ponderação a efetuar no caso concreto. Questão relativa aos danos não patrimoniais que se encontra rodeada de grande controvérsia é a de saber se o dano consistente na morte é indenizável à própria vítima (transmitindo-se necessária e imediatamente por via sucessória); mas só à custa de conceitualismo extremo pode tal hipótese ter admissibilidade. O Supremo Tribunal Administrativo (vulgo STA ) considerou que as meras angústia e incerteza causadas por uma conduta administrativa não são danos suficientemente graves para merecerem tutela em sede de responsabilidade civil (Ac. do STA de 31/5/2005, Proc. n. ${ }^{\circ} 0127 / 03$ ), mas aceitou a ressarcibilidade dos danos não patrimoniais consistentes no "desgosto, nervosismo, angústia e depressão" sofridos pelo lesado em consequência da conduta administrativa (Ac. do STA de 24/10/2006, proc. n. ${ }^{\circ}$ 0539/06). Toda a jurisprudência aqui citada se encontra disponível para consulta em www.dgsi.pt. 
que a reparação só é em dinheiro' ${ }^{13}$ quando não seja possível a reconstituição natural ou esta não a repare integralmente, ou seja excessivamente onerosa (artigo $3^{\circ}, \mathrm{n}^{\circ} 2$ do RRcivilEEE).

Quanto ao nexo de causalidade, para que haja responsabilidade civil é preciso que o dano possa ser objetivamente imputado ao fato voluntário; o último requisito da responsabilidade civil delitual é um nexo de causalidade entre o fato voluntário e o dano, estando tal exigência implícita nos artigos $7^{\circ}, \mathrm{n} .^{\circ} 1$ e $8^{\circ}, \mathrm{n} .^{\circ} 1$ do RRcivilEEE, quando se referem aos prejuízos que resultem de atos ilícitos e culposos. Em termos ontológicos, um fato é causa de um evento se o evento, sem o fato, não tivesse ocorrido. Este conceito de causa como conditio sine qua non é a base das teorias normativas da causalidade, mas por si só é imprestável, pois dela resulta um número de causas potencialmente infinito para cada resultado.

As teorias do nexo de causalidade são: a teoria da causalidade adequada, a teoria da esfera de proteção da norma

13 Quanto ao cálculo da indenização, estando em causa a indenização pecuniária torna-se necessário proceder-se àquele. Regra geral, o dano indenizável corresponderá à diferença entre a situação atual do lesado e a situação hipotética em que se encontraria atualmente, caso não tivesse ocorrido o fato lesivo ilegal (cfr, o artigo 566, n. ${ }^{\circ} 2$ do CC, e a doutrina e jurisprudência portuguesas dominantes). Considerando a teoria da diferença, aqui inerente, o dano calcula-se por comparação entre a situação patrimonial real do lesado e uma situação patrimonial hipotética (parecendo-nos ser esta teoria pacífica entre nós). Porém, a altura importante para se proceder ao cálculo indenizatório condiz, nos termos do mesmo artigo civilístico, à data mais atual que puder ser tida em conta pelo tribunal competente - seja o Tribunal Administrativo de Círculo (em $1^{\mathrm{a}}$ instância), ou o Tribunal Central Administrativo - Norte (TCAN) ou Sul (TCAS) - (observação nossa). Ademais, e agora nas palavras de Filipa Calvão, tendo em consideração o artigo $95, \mathrm{n} .{ }^{\circ} 6$, do CPTA, "(...) parece poder concluir-se que esse momento há-de corresponder à data do encerramento da fase de julgamento do processo declarativo, podendo coincidir com a data de encerramento de uma eventual fase complementar de produção de prova, como aí se prevê (em caso de cumulação do pedido de impugnação de um ato com o pedido de indenização)". Cfr. Filipa Calvão (2013, p. 102). 
e a teoria da conexão do risco ${ }^{14}$, sendo certo que convém referir a importância da causa virtual e comportamento lícito alternativo. A base ontológica da noção normativa de causalidade implica que esta se refira a fatos reais ${ }^{15}$.

A culpa do lesado pode excluir a responsabilidade do lesante ou implicar a distribuição proporcional da responsabilidade pelas esferas patrimoniais do lesante e do lesado, nos termos do artigo $4^{\circ}$ do RRcvilEEE: quando o comportamento culposo do lesado tenha concorrido para a produção ou o agravamento dos danos causados, a indenização pode ser totalmente concedida, reduzida ou excluída, consoante a gravidade das culpas de ambas as partes e as consequências que delas tenham resultado. A culpa do lesado não exclui em abstrato a efetivação da responsabilidade civil; o juízo sobre a subsistência, e em que termos, do direito à indenização será efetuado em concreto pelo tribunal na ação de indenização que for interposta. A responsabilidade do lesante é excluída de forma automática sempre que resultasse da presunção da sua culpa (art. $570, n{ }^{\circ} 2$ do $\mathrm{CC}$, disposição que deve considerar-se abrangida pela remissão do artigo $10^{\circ}, \mathrm{n} .{ }^{\circ} 3$ do RRcivilEEE para os princípios gerais da responsabilidade civil quanto às presunções de culpa administrativa especificamente consagradas). A diligência do lesado é aferida nos mesmos termos que é aferida a do lesante.

14 Vd. Marcelo Rebelo de Sousa/André Salgado de Matos (2008, p. 31). 15 Os tribunais administrativos consideram não haver nexo de causalidade entre atos administrativos materialmente válidos, mas padecendo apenas de vício de forma ou de violação de lei por falta ou vício de fundamentação, e os danos eventualmente verificados: nestes casos, os danos teriam sido produzidos na mesma se os atos administrativos em causa tivessem sido praticados sem o vício que os inquinava. Esta doutrina não põe de parte, a existência de nexo de causalidade quando o vício não substancial em causa "tiver inquestionavelmente determinado o conteúdo substancial e resolutório do ato ilegal" (Ac. do STA de 13/2/2003, Proc. n. ${ }^{\circ}$ 01961/02). Sobre o assunto, vd, Marcelo Rebelo de Sousa/André Salgado de Matos (2008, p. 32). 
A responsabilidade delitual também impende sobre os seus titulares de órgãos ou agentes que, do ponto de vista ontológico, praticaram o fato voluntário ilícito, culposo e danoso. A articulação das responsabilidades de cada um está sujeita a certas regras (artigos $7^{\circ}, n .^{\circ} 1,8^{\circ}$, n. $^{\circ} \mathrm{s} 1$ e 2 do RRcivilEEE). Os titulares de órgãos e agentes administrativos respondem pelos prejuízos resultantes de atos ilícitos praticados com dolo ou negligência grave (artigo $8^{\circ}, n .^{\circ} 1$ do RRcivilEEE), resultando daqui a irresponsabilidade dos titulares de órgãos ou agentes pelos seus atos praticados com negligência leve (solução tradicional no direito português, mas muito discutível e mesmo de duvidosa constitucionalidade, à luz do artigo 22 da CRP ${ }^{16}$; recusando a inconstitucionalidade, temos o Acórdão (Ac.) do STA de 28/9/2006, Proc. 0855/04). Isto é, a responsabilidade das pessoas coletivas administrativas pressupõe a prática de um ato ilícito e culposo por um titular de órgão ou agente, mas não pressupõe a sua responsabilidade, podendo existir responsabilidade das primeiras e não dos segundos.

A solidariedade pressupõe a responsabilidade do titular de órgão ou agente; por isso, este regime só se aplica nos casos

16 Para J. J. Gomes Canotilho e Vital Moreira: "O artigo 22, referente à responsabilidade civil ou patrimonial das entidades públicas, é um dos preceitos constitucionais que mais dúvidas tem suscitado nos planos dogmático, metódico e metodológico. Em primeiro lugar, coloca-se o problema de saber qual é o objeto de proteção. Objeto de proteção devem considerar-se, desde logo, os direitos, liberdades e garantias lesados por ações ou omissões dos titulares de órgãos, funcionários ou agentes do Estado e demais entidades públicas. Em segundo lugar, perguntase pelo sentido jurídico-constitucional do instituto da responsabilidade do Estado e demais entidades públicas. A localização deste instituto em sede constitucional significa que ele não transporta apenas uma lógica indenizatória-ressarcitória decalcada na responsabilidade do direito civil. A responsabilidade conexiona-se, desde logo, com outros princípios jurídicoconstitucionalmente estruturantes como o princípio do Estado-de-direito (arts. $1^{\circ}$ e $2^{\circ}$ ), o princípio da constitucionalidade e legalidade da ação do Estado (art $4 .^{\circ}$ ), e o princípio da igualdade (art. 13). Mas a responsabilidade dos 
de dolo ou negligência grave (artigo $8^{\circ}$, n. ${ }^{\circ} 2$ RRcivilEEE), que suscita dúvidas de conformidade constitucional.

Em regra, quando satisfaça uma indenização com fundamento em responsabilidade delitual, a pessoa coletiva administrativa deve exigir ao titular de órgão ou agente que cometeu o fato que the pague o montante da indenização suportada; a isto se chama o exercício do regresso (artigo $8, \mathrm{n}^{\circ}$ 3 do RRcivilEEE), sendo que a possibilidade de regresso apenas não existe em três situações:

1. caso a negligência do titular do órgão ou agente tenha sido leve, dado que nesse caso aquele será irresponsável (artigos $7^{\circ}, 8^{\circ}$, n. $^{\text {os }} 1,2$ e 3 do RRcivilEEE);

2. caso tenha havido funcionamento anormal do serviço, dado que nesse caso não é possível apurar a identidade do autor do fato voluntário;

3. caso o autor do fato voluntário tenha atuado ao abrigo de ordens ou instruções ilegais às quais devesse obediência e tenha exercido o seu direito de representação (havendo depois lugar a regresso contra o superior hierárquico que emitiu as ordens ou instruções).

Os órgãos aos quais incumbe a efetivação do regresso são os detentores dos poderes de direção, de superintendência ou de tutela sobre quem praticou o fato danoso (artigo $8^{\circ}, \mathrm{n} .^{\circ} 3$ do RRcivilEEE); havendo vários órgãos em tais circunstâncias, a competência é deferida pela ordem indicada). A omissão daquelas diligências é ilegal, pelo que os órgãos omitentes poderão, eles próprios, tornar-se civilmente responsáveis pela sua não adoção perante a pessoa coletiva a que pertençam. Quando uma pessoa coletiva administrativa seja condenada ao pagamento de uma indenização em virtude de presunção de culpa leve, a ação poderes públicos garante substantividade jurídico-constitucional sobretudo como um direito de defesa, legitimador de pretensões indenizatórias, contra a violação de direitos, liberdades e garantias dos cidadãos". Cfr. J. J. Gomes Canotilho / Vital Moreira (2007, p. 425). 
judicial prossegue, após a condenação, entre aquela pessoa coletiva e o responsável individual, para apuramento do grau de culpa e do eventual exercício do regresso (artigo $8^{\circ}$, n. $^{\circ} 4$ do RRcivilEEE, que, inexplicavelmente, contempla apenas a presunção de culpa do artigo 10, n. $^{\circ} 2$ do RRcivilEEE) ${ }^{17}$.

Quanto à solidariedade entre os titulares de órgãos e agentes, em caso de pluralidade de responsáveis, se houver mais do que um titular de órgão ou agente responsáveis, o artigo 10, n. ${ }^{\circ} 4$ do RRcivilEEE manda atender ao disposto no artigo 497 , n. ${ }^{\circ} 1$ do Código Civil (CC), que determina a solidariedade entre os vários responsáveis (artigo 497, n. ${ }^{\circ} 1$ do CC), estabelecendo ainda que o direito de regresso entre todos eles existe na medida das suas culpas e das consequências que delas advieram, presumindo-se serem tais culpas iguais (artigo 497, n. ${ }^{\circ} 2$ do CC). Estando esta situação regulada no CC, não é aplicável o disposto no artigo $6^{\circ}$ do RRcivilEEE.

A responsabilidade administrativa pelo risco não possui caráter excecional, definindo-se através de uma cláusula geral: as pessoas coletivas administrativas respondem pelos danos causados por atividades, coisas ou serviços administrativos especialmente perigosos (artigo 11, n. $^{0} 1$ do RRcivilEEE) ${ }^{18}$, não sendo, contudo, qualquer fato que pode gerar responsabilidade pelo risco: é preciso que esse fato resulte de uma atividade, do funcionamento de um serviço ou de uma coisa especialmente perigosos.

Quanto ao dano, não há limite qualitativo nem quantitativo à ressarcibilidade dos danos. Por conseguinte, a imputação do dano à entidade pública administrativa exige que entre o dano e a respectiva atividade, coisa ou serviço especialmente perigosos intervenha um nexo de causalidade adequada, de acordo com o

$17 \quad$ Neste sentido, Marcelo Rebelo de Sousa/André Salgado de Matos (2008, pp. 36-37).

18 Marcelo Rebelo de Sousa/André Salgado de Matos (2008, p. 38). 
artigo 563 do $\mathrm{CC}^{19}$.

Ainda na esfera jurídica do dano (nesta responsabilidade pelo risco), tal dano deve decorrer do risco inerente à atividade, coisa ou serviço, não podendo ter sido provocado por ocasião do seu exercício ou utilização - ele tem de resultar de modo específico dos perigos que estão associados àqueles ${ }^{20}$. Ora, o lesado goza de uma proteção especial em razão do risco específico da atividade (coisa ou serviço) ${ }^{21}$. Sublinhando G. Schamps (1998, pp. 935 e 940), o dano derivado de uma pessoa escorregar numa substância tóxica não deve ser avaliado em sede de responsabilidade pelo risco.

No que respeita ao nexo de causalidade (implícito na expressão "danos decorrentes de", no art. 11, n. ${ }^{\circ} 1$ do RRcivilEEE), também na responsabilidade pelo risco não difere substancialmente da responsabilidade delitual, mostrando-se aqui especialmente apropriada a teoria da esfera de proteção da norma.

A responsabilidade administrativa pelo risco pode ser excluída ou modificada em três situações: o caso fortuito ou de força maior, a culpa do lesado (ambos no art. 11, n. ${ }^{\circ} 1$, última parte do RRcivilEEE) e a responsabilidade de terceiro (art. 11, n. ${ }^{\circ} 2$ do RRcivilEEE). Estas causas são cumuláveis entre si, devendo apurar-se em que proporção cada uma delas, assim como o risco criado pela administração, concorreu para o dano.

A culpa do lesado afere-se nos mesmos termos que na responsabilidade delitual, podendo, consoante as circunstâncias, excluir ou reduzir a responsabilidade da administração (art. 11, n. ${ }^{\circ} 1$ do RRcivilEEE); no último caso, haverá que apurar em que proporção o risco criado e a culpa do lesado concorreram para a produção do dano/da lesão.

19 Neste sentido, vd, Maria da Glória Garcia/ Marta Portocarrero (2013, p. 310).

20 Maria da Glória Garcia/ Marta Portocarrero (2013, p. 310).

21 Idem. 
A responsabilidade de terceiro, depende da verificação, quanto a outrem, dos requisitos da responsabilidade civil; ao falar em "fato culposo de terceiro", a lei parece apontar só para a responsabilidade delitual daquele, mas pode também tratar-se de responsabilidade pelo risco (embora não pelo mesmo risco).

$\mathrm{Na}$ indenização pelo sacrifício, artigo 16 do RRcivilEEE, importa a especialidade e a anormalidade do dano (art. $2^{\circ}$ do RRcivilEEE), sendo certo que entendemos que esta constitui uma modalidade de responsabilidade civil extracontratual do Estado e demais entidades públicas, e não estamos perante uma mera compensação pelo sacrifício ${ }^{22}$.

$\mathrm{O}$ artigo 16 do RRcivilEEE ${ }^{23}$ encontra-se filiado num

22 Para maiores desenvolvimentos, em relação ao qual há divergência doutrinal, $v d$, Patrícia Pinto Alves (2014).

23 Vd. Patrícia Pinto Alves (2018), disponível para consulta em: http:// boletim.oa.pt/oa-07/opiniao---patricia-alves. Neste sentido, defende-se que na indenização pelo sacrifício estamos perante uma modalidade de responsabilidade civil extracontratual do Estado e demais entidades públicas por fatos lícitos, e não perante uma mera compensação pelo sacrifício, isto no âmbito da responsabilidade civil extracontratual do Estado e demais Entidades Públicas por fatos lícitos, porque embora não haja uma conduta ilícita por parte da Administração Pública (AP), situações concretas em que a AP pode (e deve) ser responsabilizada embora pela prática de uma conduta lícita, mas que provocou danos especiais ou anormais na esfera jurídica dos visados (prejudicados) em causa. A título exemplar, parece aceitável que quando a AP ache imprescindível a utilidade de construção de uma infraestrutura (autoestrada) numa determinada localidade, se exproprie da sua habitação (diga-se própria e habitual) uma determinada pessoa ou determinadas pessoas em específico, tendo estas individualidades um direito a uma indenização pelos danos que foram prejudicados nas suas esferas jurídicas (conforme se entende). Note-se que aqui o fim visado é a utilidade pública dos cidadãos em geral, mas que para ser satisfeita é prejudicada certa (s) individualidade (s) na sua esfera particular e concreta (defendemos esta posição, muito embora exista doutrina divergente a respeito). $O$ interesse geral da coletividade, nestas situações, sobrepõe-se ao interesse privado de outrem (posição por nós adotada). Parece defensável e aplicável nesta sede a ideologia do princípio da igualdade (plasmado no artigo 13 da $\mathrm{CRP}$ ), através da qual o igual deve ser tratado por igual, e o desigual deve 
princípio de justa repartição dos encargos públicos, que emana dos artigos $2^{\circ}, 13$ e 18 da CRP. Consoante a posição jurídica privada concretamente sacrificada pela ingerência administrativa, poderão estar também em causa os artigos $26, n .^{\circ} 1$ ou $62, n .^{\circ}$ 1 da CRP, isto é, perante danos de natureza não patrimonial ou patrimonial, de forma respectiva. Os pressupostos da responsabilidade civil pelo sacrifício de bens pessoais são o fato voluntário, a licitude, o dano e o nexo de causalidade.

$\mathrm{Na}$ indenização pelo sacrifício a indenização é calculada com base nos critérios definidos nas normas conjugadas dos artigos 16 e $3^{\circ}$ do RRcivilEEE. Na expropriação de sacrifício, a indenização apura-se com base no critério definido no Código das Expropriações (CE), devendo corresponder ao valor de mercado (Verkehrswert) do bem expropriado, compreendido em sentido normativo (valor de mercado normativamente entendido).

Todavia, há quem entenda que, visando que não só a expropriação ${ }^{24}$, como a indenização pelo sacrifício e a responsabilidade por ato lícito, "embora estejam contidas no mesmo preceito legal e ainda que ambas se distingam, pelas mesmas razões, da responsabilidade civil em sentido estrito, [...] são, em rigor, institutos distintos, aos quais devem corresponder diferenças práticas de regime jurídico" 25

ser tratado por desigual (defende-se que a terminologia "igualdade", deveria ser substituída por "equidade").

24 Denote-se que nos demais países Europeus, nomeadamente "na França integrou-se a expropriação na responsabilidade, ao passo que na Alemanha, ao inverso, integrou-se a responsabilidade na expropriação", mas apesar deste modelo corresponder a uma síntese bem feita da evolução dogmática nos respectivos direitos, o mesmo não pode obscurecer que a Enteignung teve origem no Aufopferungsgrundsatz e da Sonderopfertheorie dos $\S \S 74$ e 75 da Einl. ALR e deles se autonomizou de modo progressivo no decorrer do Século XIX. Cfr. Maria Lúcia Amaral (1998, p. 121), e Hartmut Maurer (2011, § 27, Rn 7, pp. 709 - 710), apud Pedro Machete (2013, p. 442). 25 Cfr. José Carlos Vieira de Andrade (2011, p. 354), apud Pedro Machete (2013, p. 439). 
A exigência de nexo de causalidade entre o fato lícito e o encargo ou dano especial e anormal retira-se implicitamente do art. 16 do RRcivilEEE pelas expressões: "imponham encargos ou causem danos".

A figura da responsabilidade pelo não restabelecimento legítimo de posições jurídicas subjetivas violadas também faz parte da responsabilidade extracontratual objetiva do Estado e demais entidades públicas (nos termos das disposições previstas no Código de Processo nos Tribunais Administrativos, arts. 45, 102, n. $^{\circ}$ 5, 166 e 178$)$.

No entanto, renomeando Carla Amado Gomes e Miguel Assis Raimundo (2010, p. 13):

"No que tange à função administrativa, o problema que imediatamente aflora, tendo em conta o princípio de reconstituição in natura da situação atual hipotética, é o da conjugação do pedido indenizatório com o efeito reconstitutivo da sentença anulatória ou de declaração de nulidade do qual este pode ser subsidiário (cfr. os artigos $4 .^{\circ}$ e $47 .^{\circ}$ do Código de Processo nos Tribunais Administrativos (CPTA)). Na verdade, quando da execução da decisão de acolhimento do pedido principal resultar a reconstituição da situação atual hipotética, essa decisão consumirá tendencialmente o pedido indenizatório ${ }^{26}$ - salvo, porventura, no tocante a danos morais ${ }^{27 "}$.

26 "Anote-se, neste particular, a mais-valia de uma disposição como o artigo 90/3 do CPTA, que permite ao juiz (na ação especial) fasear a instrução em atenção à existência de pedidos subsidiários, de entre os quais se destacam os indenizatórios", conforme explicitam Carla Amado Gomes e Miguel Assis Raimundo (2010, p. 13, nota 28).

27 Cfr. Carla Amado Gomes/ Miguel Assis Raimundo (2010, pp. 6-7). 
Tendo em conta que para Carla Amado Gomes (2012, pp. 31-32), o artigo 16 do RRcivilEEE não se trata de uma modalidade de responsabilidade civil extracontratual objetiva (por fato lícito), mas antes de uma compensação pelo sacrifício, posição esta última que não é por todos adotada, a mesma defende que " (...) a compensação será do dano emergente mas não forçosamente de todo o dano emergente".

De referir ainda que, a indenização pelo sacrifício, para João Caupers (2009, pp. 242-243): “(...) não configura uma situação de responsabilidade, antes significa algo que está "mais perto de uma situação como a expropriação por utilidade pública do que um caso de responsabilidade civil". Não podemos, porém, deixar de aludir ao defendido por Fernando Alves Correia (2012, p. 238), no que concerne ao artigo 16 do RRcivilEEE, sendo que $o$ autor acredita que, pelo menos tendencialmente, 0 legislador optou pela indenização de acordo com os cânones da expropriação de sacrifício naquelas situações em que o ato do poder público revelar uma intencionalidade ablativa de um direito de conteúdo patrimonial ou de alguma ou algumas "faculdades" ou "irradiações" de tal direito.

Ainda quanto às situações de existência de uma causa legítima de inexecução de uma sentença de um tribunal administrativo, que conferem à parte legítima um direito a uma indenização embora que por fatos lícitos, um exemplo que nos parece oportuno e devidamente adequado é o do fato de em sede de contencioso pré-contratual (artigo 100 e seguintes do Código de Processo nos Tribunais Administrativos - CPTA - processo este de natureza urgente), quando da emissão da devida e esperada emissão da sentença, o contrato já se encontrar adjudicado e realizado (embora que injustamente e ilicitamente) a um/a outro/a concorrente ou candidato/a que não o/a verdadeira merecedor/a do procedimento concursal em causa ${ }^{28}$.

$28 \quad$ Deve-se ter também em consideração o Código dos Contratos 
Posto isto, no caso de a execução de sentença ser impossível, a indenização abarca, segundo Mário Aroso de Almeida (2002, pp. 816-817):

o "ressarcimento daqueles danos que, na esfera jurídica do recorrente, se produzem em consequência da impossibilidade de obter o cumprimento de tais deveres e que, portanto, não existiriam se eles pudessem ter sido cumpridos, não cobrindo já os eventuais danos que o ato ilegal possa ter causado e que, pela sua natureza, a execução da sentença não teria sido, em qualquer caso, apta a remover, pelo que teriam subsistido mesmo que ela tivesse podido ter lugar".

Nesta sequência, a perda da situação jurídica por causa legítima de inexecução dá lugar a um dever objetivo de indenização (de acordo com os artigos 176, n. 7 e 166, n. ${ }^{\circ} 1$, ambos do (PTA), fundado na percepção de que, quando as circunstâncias vão ao ponto de nem sequer possibilitar que o recorrente obtenha aquela utilidade que, em princípio, a anulação lhe deveria proporcionar, não seria justo colocá-lo na total e exclusiva dependência do preenchimento dos requisitos da responsabilidade subjetiva da AP por fatos ilícitos e culposos sem lhe assegurar, em qualquer caso, uma indenização pela perda da situação jurídica cujo restabelecimento a execução da sentença lhe teria proporcionado ${ }^{29}$.

Neste âmbito último, a quantia indenizatória devida depende da exata configuração da pretensão que ficou insatisfeita e do quadro envolvente, de fato e de direito ${ }^{30}$. Neste sentido, há Públicos (na versão aplicável) in casu, assim como as Diretivas Recurso (transpostas) da União Europeia nesta sede.

$29 V d$. Mário Aroso de Almeida (2002, p. 281).

30 Neste sentido, Mário Aroso de Almeida (2010, p. 9). 
os Acórdãos (todos) do STA de 20-11-2012, Processo n. ${ }^{\circ}$ 949/12; de 26-09-2012, Processo n. ${ }^{\circ}$ 429-A/03 e o Acórdão de 2-12-2010, Processo n. ${ }^{\circ}$ 47579-A.

\section{BREVES CONSIDERAÇÕES FINAIS}

Aqui chegados, conclui-se pela existência, no ordenamento jurídico português, de três tipos de responsabilidade civil extracontratual do Estado e demais Entidades Públicas pelo exercício da função administrativa. Isto é, existe responsabilidade civil extracontratual delitual (por fatos ilícitos), pelo risco e por fatos lícitos.

No primeiro tipo de responsabilidade, para se estar perante a mesma, há uma obrigatoriedade de verificação cumulativa de cinco pressupostos, sendo estes uma conduta/fato voluntário, a culpa, a ilicitude daquela conduta, os danos (patrimoniais, morais, presentes e futuros) e o nexo de causalidade entre o fato e o dano.

Por sua vez, há responsabilidade pelo risco quando não há ilicitude nem culpa.

$\mathrm{Na}$ indenização pelo sacrifício (artigo 16 do RRcivilEEE), defende-se estar perante uma modalidade de responsabilidade civil, em que para que tal se verifique terá de haver uma especialidade do dano e a anormalidade daquele (cfr, o disposto no artigo $2^{\circ}$ do RRcivilEEE).

Nas situações de existência de uma causa legítima de inexecução de uma sentença de um tribunal administrativo, que conferem à parte legítima um direito a uma indenização embora que por fatos lícitos, um exemplo que parece oportuno e devidamente adequado é o do fato de em sede de contencioso pré-contratual (artigo 100 e seguintes do Código de Processo nos Tribunais Administrativos (CPTA), processo este de natureza urgente, quando da devida e esperada emissão da sentença, o contrato já se encontrar adjudicado e realizado (embora 
que injustamente e ilicitamente ) a um/a outro/a concorrente ou candidato/a que não o/a verdadeiro/a merecedor/a do procedimento concursal em causa.

\section{REFERÊNCIAS}

ALVES, Patrícia Pinto - A Responsabilidade do Estado por Imposição de Sacrifício, Porto, Bookline, 2014.

ALVES, Patrícia Pinto - A responsabilidade civil extracontratual do Estado por ato administrativo: "because ... the king can do wrong". In: Boletim da Ordem dos Advogados Portugueses, Capa 07, Janeiro de 2018, disponível para consulta in: http://boletim.oa.pt/oa-07/opiniao--patricia-alves . Acesso em: 20 nov. 2018.

AMARAL, Diogo Freitas do - Curso de Direito Administrativo, Vol. II, 2. ${ }^{\text {a }}$ ed., Coimbra, Almedina, 2011, pp. 742-744.

AUBY, Jean-Bernard / MOREAU, Responsabilité Définitions. Principes. Orientation, Juris Classeur Administratif, 2010, Fasc. 81, anotation n. ${ }^{\circ} 66$.

CADILHA, Carlos Alberto Fernandes - 0 novo regime de responsabilidade civil do Estado e demais entidades públicas pelo exercício da função administrativa, disponível em: https://www.csm.org.pt/ficheiros/eventos/ encontroscsm/06eacsm/6encontrocsm_carloscadilha2.pdf . Acesso em: 15 nov. 2018.

CALVÃO, Filipa - Comentário ao Regime da Responsabilidade Civil Extracontratual do Estado e 
demais Entidades Públicas, in: Rui Medeiros (org.), Lisboa, Universidade Católica Editora, 2013, p. 102.

CAUPERS, João - Introdução ao Direito Administrativo, 10. ${ }^{\text {a }}$ ed., Lisboa, Âncora, 2009, pp. 242-243.

CORREIA, Fernando Alves - Estudos em homenagem ao Prof. Doutor José Joaquim GOMES CANOTILHO. In: STVDIA IVRIDICA, 102, AD HONOREM - 6, Vol I, "Responsabilidade entre Passado e Futuro", Boletim da Faculdade de Direito da Universidade de Coimbra, Coimbra Editora, 2012, p. 213.

CORREIA, Fernando Alves - Manual de Direito do Urbanismo, Vol. II, Coimbra, Almedina, 2010, 131-167, 171174 e pp. 384-389.

CORREIA, Fernando Alves - As Garantias do Particular na Expropriação por Utilidade Pública, Coimbra, Almedina, 1982, pp. 47-76.

CORTEZ, Margarida - Responsabilidade civil da Administração por Actos Administrativos llegais e Concurso de Omissão Culposa do Lesado, Coimbra Editora, 2000, pp. 104-105.

DETTERBECK/ WINDTHORST/SPROLL,

Staatshaftungsrecht, 2000, p. 204-205, § 11, anotação 10, pp. 204-205.

FONSECA, Isabel - "Violação do prazo razoável e reparação do dano: quantas novidades, mamma mia!". In: CJA, n. ${ }^{\circ} 72,2008$, inserido in: A Batalha pela tutela e 
urgência, Estudos de direito processual administrativo (europeu), Porto, 2011, pp. 189 e ss.

GOMES, Carla Amado - "A compensação administrativa pelo sacrifício: reflexões breves e notas de jurisprudência”. In: Revista do Ministério Público, n. ${ }^{\circ} 129$, Janeiro/Março, 2012, pp. 31-32.

GOMES, Carla Amado / RAIMUNDO, Miguel Assis "Topicamente - e a quatro mãos...- sobre o novo regime da responsabilidade civil extracontratual do estado e demais entidades públicas". In: Revista de Direito Público e Regulação, n. ${ }^{\circ} 5$, Março, ed. Centro de Estudos de Direito Público e Regulação (Cedipre), FDUC, 2010, pp. 6-7.

GOMES, Carla Amado - "ABC da (i)responsabilidade dos juízes no quadro da lei $n .^{\circ}$ 67/2007, de 31 de Dezembro". In: [SI], n. ${ }^{\circ} 322,2010$, pp. 261 e ss.

MACHETE, Pedro - Artigo 16. - "Indemnização pelo sacrifício", Comentário ao Regime da Responsabilidade Civil Extracontratual do Estado e demais Entidades Públicas. In: Rui Medeiros (org.), Lisboa, Universidade Católica Editora, 2013, p. 439.

MAURER, Hartmut- Allgemeines Verwaltungsrecht, 18, Auflage, 2011, § 27, Rn 7, pp. 709 - 710.

MESQUITA, Maria José Rangel de - "Irresponsabilidade do Estado-juiz por incumprimento do Direito da União Europeia: um acórdão sem futuro". In: CJA, n. ${ }^{\circ} 79,2010$, pp. 29 e ss. 
PÉRES, Jesús González - Responsabilidad patrimonial de las administraciones públicas, $5 .^{a}$ ed., 2009, pp. 348-352.

SCHAMPS, G. - La mise en danger: un concept fondateur d'un principe général de responsabilité. Analyse de droit comparé, 1998, pp. 935 e 940.

SOUSA, Marcelo Rebelo de / MATOS, André Salgado de - Responsabilidade Civil Administrativa, Direito Administrativo Geral, Tomo III, $1 .^{a}$ ed., (reimpressão da $1 .^{a}$ edição: Julho de 2010), Lisboa, Dom Quixote, 2008, pp. 16-17; p. 20; p. 21; pp. 25-26; pp. 26-27; p. 31; p. 32; pp. 36-37; p. 38.

VIEIRA DE ANDRADE, José Carlos - "A Responsabilidade indemnizatória dos poderes públicos em 3D: Estado de Direito, Estado Fiscal, Estado Social”. In: RLJ, ano 140, n. ${ }^{\circ}$ 3969, 2011, p. 354.

Jurisprudência:

Acórdão do TCAN de 21-10-2016, processo n. ${ }^{\circ}$ 02595/12.7BEPRT - TAF do Porto - disponível em: www.dgsi. pt . Acesso em: 12. nov. 2018.

Acórdão do STA de 20-11-2012, processo n. ${ }^{\circ}$ 949/12, disponível em: www.dgsi.pt . Acesso em: 12. nov. 2018.

Acórdão do STA de 26-09-2012, processo n. ${ }^{\circ} 429-A / 03$, disponível em: www.dgsi.pt . Acesso em: 12. nov. 2018.

Acórdão do STA de 2-12-2010, processo n. ${ }^{\circ}$ 47579-A, disponível em: www.dgsi.pt . Acesso em: 10. nov. 2018.

Acórdão do STA de 13-02-2003, processo n. ${ }^{\circ}$ 01961/02, disponível em: www.dgsi.pt . Acesso em: 10. nov. 2018. 
Acórdão do STA de 31-05-2005, processo n. ${ }^{\circ} 0127 / 03$, disponível em: www.dgsi.pt . Acesso em: 10. nov. 2018.

Acórdão do STA de 16-05-2006, processo n. ${ }^{\circ}$ 0121/06, disponível em: www.dgsi.pt . Acesso em: 10. nov. 2018.

Acórdão do STA de 28-09-2006, processo n..$^{\circ}$ 0855/04, disponível em: www.dgsi.pt . Acesso em: 09. nov. 2018.

Acórdão do STA de 24-10-2006, processo n. ${ }^{\circ}$ 0539/06, disponível em: www.dgsi.pt . Acesso em: 09. nov. 2018.

\section{Legislação:}

Código Civil Português;

Código das Expropriações Português;

Constituição da República Portuguesa Anotada;

Lei n. ${ }^{\circ}$ 67/2007, de 31 de Dezembro - Lei da Responsabilidade Civil Extracontratual do Estado e demais Entidades Públicas Portuguesa.

Recebido em | 23/01/2019
Aprovado em | 11/03/2019

Revisão Português/Inglês | Letícia Gomes Almeida

\section{SOBRE A AUTORA | ABOUT THE AUTHOR}

Doutoranda em Direito Público na Faculdade de Direito da Universidade de Coimbra - Portugal. E-mail: patriciapintoalves26@ gmail.com. 